\title{
6
}

\section{LINES IN THE SNOW: THE MAKING OF THE RUSSO-JAPANESE FRONTIER}

In that web of intersecting tragedies we call 'the Second World War', one of the most curious conflicts was surely the three-week war between the Soviet Union and Japan, which broke out on 8 August 1945, and ended several days after Japan's official surrender to the allied powers. Perhaps the shortest of the many wars within the war, it has created the most prolonged and intractable search for peace. Today, more than 75 years after the event, the Japanese and Russian governments have yet to sign a peace treaty. Their main stumbling block has been conflict over the Russo-Japanese frontier: specifically, over Japan's claims to the islands of Shikotan, Kunashir (or Kunashiri), Iturup (or Etorofu) and the Habomai group, seized by Soviet troops (along with the rest of the Kurile island chain and the southern half of Sakhalin) during those three weeks of fighting in August 1945. As in many border disputes, even the place names are bones of contention. The Russian government calls these islands the Southern Kuriles, while the Japanese state denies that they are part of the Kurile archipelago, and refers to the region as the Northern Territories $\left(\right.$ Hoppō Ryōdo). ${ }^{1}$

1 T Ishiwatari, 'The Northern Territories', in Contested Territory: Border Disputes at the Edge of the Former Soviet Empire, ed. T Forsberg (Aldershot: Edward Elgar, 1995), pp. 224-54. 
What fascinates me about this story is not so much the glacially slow progress of international diplomacy, but rather the nature of the frontier itself: the arbitrary, moveable line that separates Russia from Japan, and now runs between Hokkaido to the south and the islands of Habomai, Kunashir and Sakhalin to the north. On the crossing from Hokkaido to Sakhalin in the summer of 1996, I encountered a man who had lived all his life in a house overlooking Wakkanai harbour. Every clear day he had looked out of his bedroom window at the dark line of the Sakhalin coast on the horizon. But for the first 30 years of his life it was as inaccessible as the moon. Now he was going to set foot on it for the first time.

This is not simply a border between nation and nation. Across the water, as guidebooks inform the small trickle of Japanese tourists who make this journey, lies 'the Europe closest to Japan'. In geographical terms, of course, Europe and Asia are separated by that other arbitrary line, drawn along the ridge of the Ural Mountains by Philip-Johann von Strahlenberg in the eighteenth century, and bisecting Russia between the two continents. But in political, social and imaginative terms, the border between Japan and Russia, which currently runs between Hokkaido and Sakhalin on its western side and between Hokkaido and the islands of Kunashir and the Habomai Group on its east, is indeed a point where Europe and Asia meet. On one side the language is Russian and the population dominated by immigrants from European Russia; on the other, the language and the vast majority of the people are Japanese. To the north, the crumbling stucco apartment blocks - their stairwells exuding smells of cool stone, musty plaster and strong cigarettes - could be buildings in St Petersburg, Kyiv or Warsaw, as could the bakeries with their displays of black bread and buns filled with sour plum jam. To the south, the huddle of shops near the harbour selling souvenir boxes of rice crackers and seaweed, the blueroofed houses, the tangles of telephone wires and the gleaming cylinder of the All Nippon Airways Hotel are unmistakably Japanese, even though many shops now boast signs in Russian to cater to the regular influx of customers from the Sakhalin fishing fleet.

And then again, from 1945 to the end of the 1980s, this was the borderline between another sort of East and West: the two poles of the Cold War. But at that time, in defiance of Kipling's logic, it was a meeting point where (geographical) East was (political) West and vice versa. The paranoias of the Cold War period are still preserved in the almost identical arrays of enigmatic pylons, aerials and puffball domes lining both sides 
of the straits - a technology of espionage and early warning systems that, amongst other things, sent the crew and passengers of Korean Airlines Flight 007 to their deaths in 1983 for flying into the wrong piece of air.

\section{Frontiers, Borders and Boundaries}

National frontiers are vantage points from which to explore shifts in the world order, to rediscover 'globalisation' as a phenomenon that is neither particularly recent nor implies the disappearance of borderlines. 'Globalisation', in this sense, implies the long historical process of the ordering of human difference through the worldwide replication of common social forms: forms often imposed by conflict between unequal forces. One of these forms is the border itself. Since the eighteenth century, the boundaries between nations have acquired certain standard, internationally recognised characteristics. Yet these characteristics have changed over time, reflecting shifts in the nature of the world order. Though every frontier is unique, tracing the history of a particular frontier is a way of reflecting on some of the wider changes in the meaning, symbolism, social presence and economic influence of the lines that surround the nation-state. A focus on the boundaries between nations, rather than on the nation itself, also provides a perspective that reminds us how much nation-building is a contingent process, an uncertain interplay of forces from without as well as from within.

My purpose here is to map out the processes by which a Russo-Japanese border came into being: the way in which the area became defined as a frontier zone. I am also interested in comparing the way in which Russian and Japanese officials, colonisers and others, approaching the same region from different directions, created repertoires of imagery of the border area: images that to some degree influence the negotiation of the boundary to the present day.

\section{Naming the Region: Siberia and Ezo}

Anssi Paasi points out the importance of naming in the creation of frontier identities. Endowing a particular region with a name gathers together 'its historical development, its important events, episodes and memories and 
joins the personal histories of its inhabitants to this collective heritage'. ${ }^{2}$ The names given to regions, or the unconscious decision to leave areas anonymous, influences the way in which geographical space is imagined by policymakers, colonists, merchants and diplomats, and this imagination in turn subtly influences the physical appropriation and exploitation of the frontier terrain. As the mercantile power of Russia and Japan began to penetrate the world surrounding the Okhotsk Sea from about the seventeenth century onward, the naming of the region created a framework for rival and shifting imaginative claims to the frontier.

From the Russian perspective, the Okhotsk shoreline, Sakhalin, Kamchatka and the Kurile Islands were initially the remotest limit of a vast region stretching eastward in the mind from the Ural Mountains, and known as Tartary or, in Russian from the sixteenth century onward, as Sibir: Siberia. Russia's foothold in the eastern fringes of this region began to be established in the middle of the seventeenth century, when (as we have seen) groups of Cossack freebooters, intent on extracting tribute (yasak) from the local peoples, reached the mouth of the Amur River. The Treaty of Nerchinsk, signed with the Chinese empire in 1689, confined the Russians to the areas north of the river, and in the decades that followed Russian expansion moved northward into the Kamchatka Peninsula and the northern Kurile Islands.

Mark Bassin's wonderful study of the notion of 'Siberia' reveals the multiple levels of meaning that were attached to this term by eighteenthand nineteenth-century Russian travellers, writers, ethnographers and political activists. During the eighteenth century, Siberia or Great Tartary was seen above all as a colonial possession, rivalling the possessions of other European powers as a source of precious raw materials; but in the Siberian case, the chief resource was not gold or silver but fur - 'soft gold', as it was commonly called. This exotic imperial possession, evocatively described as 'our Peru', 'our Mexico' or 'our East India', was a source not only of material wealth but also of a rich array of images of otherness. ${ }^{3}$

2 Anssi Paasi, Territories, Boundaries and Consciousness: The Changing Geographies of the FinnishRussian Border (Chichester and New York: John Wiley and Sons, 1996), p. 35.

3 Mark Bassin, 'Inventing Siberia: Visions of the Russian East in the Early Nineteenth Century', American Historical Review 93, no. 3 (1991): pp. 763-93, doi.org/10.2307/2162430; see also Yuri Slezkine, Arctic Mirrors: Russia and the Small Peoples of the North (Ithaca and London: Cornell University Press, 1994), chs 2-3. 
By the early nineteenth century, however, the fur trade was in decline and Russian images of the eastern frontier region began to take on new forms. At one level, its harsh climate, and its expanding role as a place of exile for criminals and dissidents, imbued the very word 'Siberia' with overtones of darkness and terror. This vision of an icy wilderness where human hearts became as hard as the frozen soil was to survive into the twentieth century, and was reinforced, for example, in Anton Chekhov's famous account of his journey to the penal settlements of Sakhalin in $1890 .{ }^{4}$ At the same time, though, the wide open steppes of Siberia, untainted by the legacy of serfdom, could also be imagined as Russia's equivalent to the American frontier: a region rich, not only in land and natural resources, but also in possibilities for the construction of a new society. Thus in the 1850s political and social thinker Alexander Herzen (1812-60) envisaged Russia's eastward expansion into Siberia and the United States' westward expansion to the Pacific as two flanks of a single great movement towards freedom and human prosperity: both Russia and the United States, he wrote,

\begin{abstract}
are poor in tradition and take as their first step a complete break with the past; both swim through endless valleys searching for their borders, and from different sides have traversed awesome expanses. They have everywhere marked their path with cities, villages and colonies, up to the shores of the Pacific Ocean, the Mediterranean of the future. ${ }^{5}$
\end{abstract}

From the Japanese perspective, on the other hand, the region bordering on the Okhotsk Sea was, during the seventeenth and eighteenth centuries, perceived as being part of a more restricted but no less vaguely defined area known as 'Ezo', which extended northward from the island now called Hokkaido into the dimly perceived mists beyond. Though furs and eagle feathers were among the booty brought back from Ezo to the markets of Japan, the most important resource here was not the 'soft gold' of Siberia but rather a more prosaic product - 'golden fertiliser' (kinpi), large quantities of herring and other fish that were caught and gutted by Ainu forced labourers and then sent south to enrich the rice fields of Honshu. By the 1750s, as the first Russian traders and missionaries were

4 Bassin, 'Inventing Siberia', pp. 771-75; Anton Chekhov, The Island: A Journey to Sakhalin, trans. Luba Terpak and Michael Terpak (New York: Washington Square Press, 1967).

5 Quoted in Bassin, 'Inventing Siberia', p. 789. 
venturing into the northern Kurile Islands, the Japanese merchants were establishing their first fishing and trading posts at the southern end of the archipelago, in Kunashir. ${ }^{6}$

Just as Tartary or Siberia offered images of the exotic, which European Russians mobilised in creating images of self, so Ezo was a source of visions of otherness, which fed a slowly emerging consciousness of Japan as a nation. Perceived (following the Chinese model) as a 'barbarian periphery', Ezo was at first depicted in language full of magic and the monstrous. A fourteenth-century Japanese scroll described the 'thousand isles of Ezo' (Ezo-ga-chishima) as inhabited by cannibals, shape-shifters and female demons. With increasing contact, though, both geographical and social contours began to become more distinct. Travellers' tales from as far afield as Kamchatka (where a number of Japanese fishermen were cast ashore by storms in the seventeenth and eighteenth centuries) helped to resolve the vague image of 'northern barbarians' into a more complex awareness of a multiplicity of peoples: 'Ezo', 'Santan', 'Sumurenkur', 'Red Ezo' and others. Russian goods started to reach Japan through the trade route that extended from Kamchatka down the Kurile island chain to Hokkaido, and growing consciousness of a new colonising presence to the north encouraged the Japanese shogunate to dispatch the missions of Mamiya Rinzō, Mogami Tokunai and others to explore and map the further reaches of Ezo. ${ }^{7}$

One of the human groups that attracted the most interest from Japanese scholars of the region was (as we have seen) the tribe originally known as the 'Red Ezo' (because of the colour of their hair). By about the 1780s, it had been established that these warlike people, who were increasingly encroaching on Japanese fishing grounds in the north, were none other than the group described in foreign texts as 'Oroshiya' (Russians) and originating from the land of Muscovia, somewhere to the east of Holland (Holland being the European country most familiar to Japanese scholars). ${ }^{8}$

6 Kaiho Mineo, Kinsei no Hokkaidō (Tokyo: Kyōikusha, 1979), p. 89; Hokkaido was given its present name in 1869. Before that it, together with the rest of the region to the immediate north, was 'Ezo'. Here, however, I use the name 'Hokkaido' throughout for the sake of clarity.

7 Mamiya Rinzō, Tōdatsu Kikō (Dairen: Minami Manshū Tetsudō Kabushiki Kaisha, 1938), original written in 1810 and first published in 1911; Mamiya Rinzō, 'Kita Yezo Zustesu or a Description of the Island of Northern Yezo by Mamiya Rinsō', trans. John A Harrison, Proceedings of the American Philosophical Society 99, no. 2 (1955): pp. 93-111.

8 Kudo Heisuke, Aka-Ezo Fūsetsukō (1781), reprinted in Hoppō Mikōkai Komonjo Shūsei, ed. Terasawa Hajime et al., vol. 3 (Tokyo: Sobunsha, 1988), pp. 29-51; see also Donald Keene, The Japanese Discovery of Europe, 1720-1830, rev. ed. (Stanford: Stanford University Press, 1969). 
When the Russian explorer Golovnin was captured by the Japanese in Iturup in 1811 and held as a prisoner for two and a half years, he found himself in the uncomfortable and unusual position of being the object of the insatiable curiosity of Japanese officialdom. Although he and his companions were generally well treated by their captors, he was later to complain of the endless stream of Japanese inquisitors who had insisted on asking him 'useless' questions, apparently arising from 'mere curiosity': 'what kind of dress does the Emperor of Russia wear - what does he wear on his head - what kind of birds are found in the neighbourhood of St Petersburg - what would be the price in Russia of the clothes which they were wearing'. ${ }^{9}$ He was, in short, experiencing the trials and tribulations of being the object of early ethnographic research.

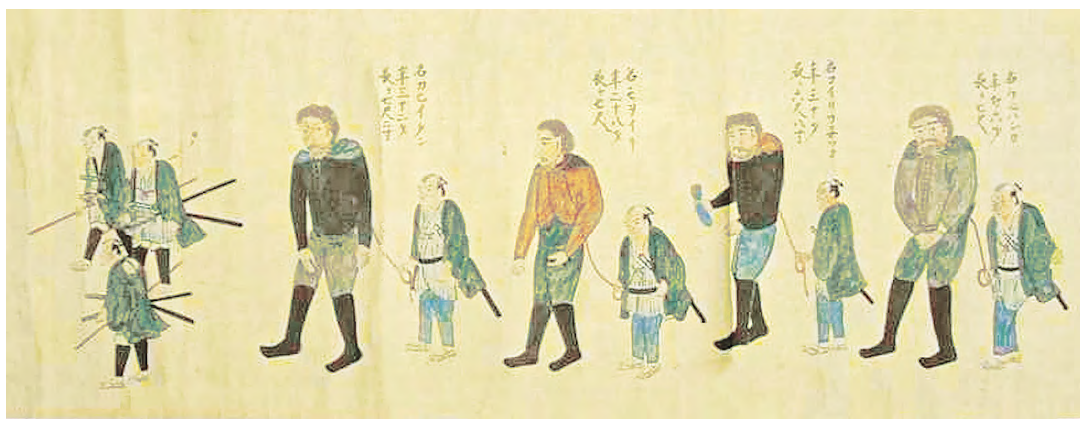

Figure 6.1. Golovnin being taken prisoner in Japan, c. 1811.

Source: Artist unknown, original held in Waseda University Library.

While images of 'Ezo' resembled images of 'Siberia' in their emphasis on the exotic qualities of the region, in other senses the early nineteenthcentury Japanese vision of the frontier region differed from the Russian vision. The heterodox philosopher Andō Shōeki (1703-62) used travellers' accounts of Ainu society to depict his image of a utopian world without rulers or ruled, where all people lived in peace with one another. The 'Ezo' (Ainu), he wrote:

catch fish, [and] gather fruit which they store up; they make clothes from the bark of trees and they never need suffer from cold, nor do they go hungry ... People engage in direct cultivation and make their own clothes by their own labour. There is no circulation of bullion, and thus people are not avaricious. There is no instruction

9 VM Golownin, Memoirs of a Captivity in Japan, ed. J McMaster, vol. 1 (Oxford: Oxford University Press, 1973), pp. 200 and 211-12. I have used the standard modern transliteration of Golovnin's name. 
on military strategy and no books of sages to disturb them about the wars and turmoil in this world ... There is no need to pass judgment as between good and evil as the people live a peaceful and quiet life. ${ }^{10}$

This wistful nostalgia has certain resonances with the writings of some nineteenth-century Russian romantics, who wrote of Siberian villages where ancient Russian traditions had been preserved in unadulterated form, and praised the 'simplicity' and 'geniality' of the indigenous peoples. ${ }^{11}$ But although Japanese travellers' accounts, naturally enough, emphasised the intensely cold climate of the northern regions, there was little to suggest an image of 'Ezo' as a grim, dark or inhospitable realm. By the eighteenth century a few Japanese scholars of Western learning were beginning to propose schemes for the colonisation and 'opening up' of Ezo, and this interest in the region was intensified by increasing anxiety about events on the frontier, but there was also, as yet, nothing to compare to the images of the Siberian frontier as a second America a land of boundless human progress. It was not until the second half of the nineteenth century, and the advent of the modernising Meiji government, that these schemes would be put into effect and the region (under a new name) would become the focus of utopian dreams of progress.

\section{Defining the Frontier}

From the Russian perspective, then, until the middle of the nineteenth century, the eastern fringes of the empire conjured up visions of a frontier in Frederick Jackson Turner's sense: 'the hither edge of free land', a phenomenon utterly different from the Western European frontier, 'a fortified boundary line running through dense populations'. ${ }^{12}$ As one political exile recalled:

Not only did there exist no frontiers, but the two neighbouring empires [here the author is referring to Russia and China] did not know accurately what distance separated them, and what was

10 Quoted in E Herbert Norman, Andō Shöeki and the Anatomy of Japanese Feudalism (Tokyo: The Asiatic Society of Japan, 1949), p. 233.

11 Sakakura Genjirō, Ezo zuihitsu, reprinted in Hoppō Mikōkai Komonjo Shüsei, ed. Terasawa Hajime et al., vol. 1 (Tokyo: Sōbunsha, 1979). Original written in 1739.

12 Frederick Jackson Turner, The Significance of the Frontier in American History (Harmondsworth: Penguin, 2008), p. 2. Original published in 1893. 
in the interior. From the Siberian side, as well as from that of the Celestial Empire, stretched out uninhabited deserts, with their steppes, their gigantic cedar-forests, their endless prairies. ${ }^{13}$

From the Japanese point of view, on the other hand, an emerging awareness of Russian expansion into this frontier region produced (at first) a rather different image of the frontier, not as a zone of forward advance but as a buffer: an area necessary both for self-protection and for cautious interchange with the outside world. This notion was captured in the metaphor, popularised from the mid-eighteenth century onward, of Ezo as Japan's 'northern guard-house' or 'northern gate' (bokumon).

Increasing conflict with the 'Red Ezo' to the north of the gate, however, created a new imperative to define its geography more precisely, and this in turn gradually gave rise to a different vision of the frontier. In 1789, a revolt by Ainu broke out on the island of Kunashir and the neighbouring coastal area of northern 'Ezo' in protest against the treatment of local people by Japanese merchants, and in the autumn of 1806 and spring of 1807, two hot-headed Russian adventurers named Khvostov and Davydov, enraged by Japan's rebuff to a diplomatic mission from the Tsarina Catherine, attacked and burnt Japanese trading posts in southern Sakhalin and on the Kurile island of Iturup. Although the Russian government publicly disowned this exploit, it caused intense concern to the Japanese shogunate. One response was to dispatch Mamiya Rinzō and Matsuda Denjirō, to explore the northern regions of Ezo and to locate 'the limits of the territory of Great Japan' (Dai-Nihonkoku no jizakai). ${ }^{14}$

From a modern perspective, there is something slightly strange about this mission - this vision of the border as a tangible phenomenon, almost like a mountain range or a rift valley, which must exist out there somewhere, even though no one yet knows where. It suggests a notion of the frontier in some respects similar to the early nineteenth-century Thai concepts illuminated by the research of Thongchai Winichakul. Here the frontier is seen not as a sharp line, but rather as a zone, or perhaps more accurately a series of points, which mark the limit of the state's influence. ${ }^{15}$ In this sense, it is not the outcome of negotiation between nation and nation, but is determined by discovering how far one can travel without arriving

13 Ludwik Niemojowski, Siberian Pictures, vol. 1 (London: Hurst and Blackett, 1883), p. 3940.

14 Hora Tomio, Mamiya Rinzō (Tokyo: Yoshikawa Kōbunkan, 1960), pp. 134-37.

15 Thongchai Winichakul, Siam Mapped: A History of the Geo-Body of the Nation (Honolulu: University of Hawai'i Press, 1994), pp. 74-80. 
in something clearly 'hostile territory', and how far afield one can detect faint traces of trade or tributary connections to the state. Mamiya and Matsuda, journeying by foot and by small boat through Sakhalin, placed this limit somewhere around the region of Cape Rakka, up to which the indigenous people showed some familiarity with the existence of the Sisa (Japanese), but beyond which lay the sea to the west and impenetrable forest to the north.

Meanwhile, though, the Japanese shogunate, in response to the disturbing events to the north, was starting to engrave the frontier more firmly in the lives of the people of the region. In 1899 the eastern part of 'Ezo-chi' was placed under direct Shogunal rule, and in 1807 this was extended to the western part too. The shogunate used its new powers to attempt policies to 'Japanise' the Ainu by forcing them to learn Japanese language and wear clothes similar to those of Japanese peasants, but these measures proved to have limited success and were rather short-lived: in 1821, Matsumae Domain's authority over 'Ezo-chi' was restored and the 'Japanisation' measures lapsed until they were revived with new vigour by the modernising Meiji state from the 1870 s onwards. ${ }^{16}$

A distinctly different concept of the border is evident in the major nineteenth-century Russian expeditions to the region: the Amur expeditions of the 1850s. Unlike the travels of Mamiya and Matsuda, these were large and well-equipped ventures involving military troops, geologists, botanists and ethnographers, and backed by the wealth of the Russian-American Trading Company and by the authority of the newly created Russian Geographical Society. The prime mover behind the missions, Count Nikolai Nikolaevich Murav'ev, governor of Eastern Siberia, saw the aim as being not to locate the limits of Russian rule, but rather to stake Russia's claim to the right to territorial expansion.

This right was interpreted in at least three ways. In moral terms, Russia was seen as occupying the unique position of a European power that also possessed an Asian dimension, and thus had a special mission to bring civilisation to Asia. Pragmatically, expansion on the Pacific coast was explained in terms of the power politics of the day: if Russia did not take control of the region around the mouth of the Amur, it was likely to fall

16 See Watanabe Kyōji, Kurofune Zenya: Roshia, Ainu, Nihon no Sangokushi (Tokyo: Yōsensha, 2010), ch. 6; also Tessa Morris-Suzuki, 'Creating the Frontier: Identity and History in Japan's Far North', East Asian History 7 (1994): pp. 1-24. 
into the hands of France or Britain, with whom Russia was fighting the Crimean War. But at the same time, Russian redefinitions of its border were also justified in terms of a global system of international law, by reinterpreting the meaning of earlier interstate treaties or renegotiating the treaties themselves. So Murav'ev's emissary, Captain Gennadii Ivanovich Nevel'skoi, having explored the Straits of Tartary and coastline of Sakhalin, proposed that the island had never been part of the Chinese empire, but was rather a natural extension of the coastal regions granted to Russia by the highly ambiguous terms of the seventeenth-century Treaty of Nerchinsk. ${ }^{17}$ To emphasise the point, he went on to establish a military camp adjacent to the main Japanese trading post in southern Sakhalin. Meanwhile, Murav'ev was also placing pressure on the northern borderlands of China, whose power was weakened by the ongoing Taiping rebellion (1850-64). This pressure was ultimately to result in the 1858 Treaty of Aigun, under which China ceded to Russia a large stretch of territory along the northern bank of Amur River and the northern borders of Manchuria.

It was this modern version of the national border as a line to be negotiated through complex power plays between state and state that was also to prevail in the negotiations between Japan and Russia. By the 1850s, Japan was being drawn into the global system of nation-states by pressures from the United States and the Western European powers, as well as from Russia. In 1853, Russian emissary Yevfimiy Putyatin arrived in Japan to negotiate the frontier with the shogunate. Building on Murav'ev's claims to territory extending the Siberian coast south to the Amur River, Putyatin argued that Sakhalin, as a mere offshore appendage of this coast, was equally Russian territory. In response, Japanese officials began to deploy a relatively new concept that would become central to their subsequent definitions of national sovereignty. They argued that the Ainu people who inhabited Hokkaido, the south Kurile Islands and the southern half of Sakhalin, had traditionally been under the 'protection' of the Japanese domain of

17 Mark Bassin, 'The Russian Geographical Society, the "Amur Epoch" and the Great Siberian Expedition 1855-1863', Annals of the Association of American Geographers 73, no. 2 (1983): pp. 24056, doi.org/10.1111/j.1467-8306.1983.tb01411.x; AI Alekseev, Amurskaya Ekspeditsiya 1849-1855 (Moscow: Mysl', 1974), p. 77. Murav'ev himself expressed scepticism at this rather farfetched interpretation of geography, although he was to claim that the 1858 Treaty of Aigun, which ceded the area south of the Lower Amur to Russia, also conferred sovereignty over Sakhalin; see Akizuki Toshiyuki, Nichirō Kankei to Saharintō: Bakumatsu Meiji Shoki no Ryōdo Mondai (Tokyo: Chikuma Shobō, 1994), p. 138. 
Matsumae, and that Ainu territory was therefore Japanese territory. ${ }^{18}$ This was a crucial step in the gradual process of dispossession, by which the indigenous people on both sides of the frontier were reassigned from the role of exotic foreigners to that of national subjects, whose links to the land no longer empowered themselves, but instead empowered the territorial claims of the colonising nation-state. The Russians too were intermittently to use the presence of Nivkh-speaking indigenous groups on both sides of the Tartar Straits to reinforce their claims to Sakhalin.

Putyatin's negotiations resulted in the 1855 Treaty of Shimoda, which divided the Kurile archipelago between Japan and Russia (with the border running between the islands of Iturup and Urup) but left Sakhalin under the joint sovereignty of both nations. In practice, however, joint sovereignty proved a cumbersome arrangement, and in 1875 the frontier was renegotiated, with Japan surrendering its rights to Sakhalin in return for control of the entire Kurile archipelago. Predictably, this was done without any reference to the wishes of the indigenous inhabitants, whose lives were in many cases to be drastically affected by the new arrangements. About one-third of the Ainu population of Sakhalin were persuaded to move south to the island of Hokkaido where, concentrated in large settlements for the first time in their lives, many died of infectious diseases. In the northern Kuriles meanwhile, a large proportion of the Ainu and Aleut inhabitants had been converted to Orthodox Christianity. Of these, a few moved north to Kamchatka on the Russian side of the border (where some of their descendants remain to the present day), while the remainder were relocated by the Japanese government to the southernmost island of Habomai, for fear that their presence near the new boundary might create security problems. ${ }^{19}$ They too were decimated by poverty and epidemics resulting from their forced removal from their homes. Japan's victory in the Russo-Japanese War in 1905 then enabled Japan to regain control of the southern half of Karafuto, creating a new borderline at the 50th parallel across the island (discussed further in the following chapter).

18 See John J Stephan, The Russian Far East: A History (Stanford: Stanford University Press, 1994), pp. 48-49; Akizuki, Nichirö Kankei, pp. 14-42.

19 Karafuto Ainu Shi Kenkyūkai, ed., Tsuishikari no Ishibumi (Sapporo: Hokkaidō Shuppan Kikaku Sentā, 1992); VO Shubin, 'Zhizn "Kuril'tsev" na Kamchatke v 1877-1888 godax', Kraevedechesk Byulleten (Yuzhno-Sakhalinsk) 3, no. 4 (1992): pp. 37-52. 


\section{Nation-Building and the Frontier Zone: Priamur and Hoppō}

In the years that immediately followed the 1855 definition of the border, Russians and Japanese began to appropriate the frontier zone in new ways, both physically, though colonisation, and mentally, through a renaming of the region. From the Russian perspective, the area bordering the Okhotsk Sea ceased merely to be the remotest fringe of Siberia, and became a region geographically integrated by the labels 'Maritime Region' (Primorye) or 'Amur Region' (Priamur): labels that were to be deployed in various ways in the course of modern history. Initially, from 1856 onwards, Kamchatka, the Kuriles, Sakhalin and the Okhotsk coastline including the mouth of the Amur were incorporated into the Maritime Region (Primorskaya Oblast), and in 1884 this became part of the larger Priamur governor-generalship, subsequently renamed the Priamur Region (Priamurskii Krai).

At one level, increasing use of the region as a place of exile for the state's most feared criminals and political prisoners served only to intensify its grim reputation, and throughout the late nineteenth and early twentieth centuries, interwoven images of hostile nature and savage humanity often threatened to overwhelm more romantic depictions of the frontier. Russian convicts had first been brought to the island of Sakhalin in 1859 to dig for coal, and in 1881 the island was formally designated a penal colony; by 1897 its population was recorded as consisting of 23,251 convicts, 11,997 Russian free settlers, a small number of Chinese, Japanese and Koreans, and 4,151 indigenous people. ${ }^{20}$ The terrible conditions of exile life, vividly depicted by Anton Chekhov and others, cast their shadow of images of the landscape itself. Sakhalin became 'the Banished Island' or 'the Isle of Misery', where even time, constrained by the bonds of the katorga (penal colony), seemed unable to flow freely as it did elsewhere. For the exile, wrote one observer:

each year does not consist of twelve months ... nor does it consist of 'four seasons', as it does for people in normal society. It is not made up of 365 days, as it is for everyone else. It is millions of minutes, of which many stretch as long as eternity. ${ }^{21}$

20 John J Stephan, Sakhalin: A History (Oxford: Clarendon Press, 1971), pp. 67-68; Tōa Dōbunkai, ed., Karafuto oyobi Kita Enkaishū (Tokyo: Tōa Dōbunkai, 1905), part 2, pp. 24-26.

21 VM Doroshevich, Sakhalin: Katorga (Moscow: I. D. Sytin, 1903), p. 324; see also Ferdinand Ossendowski, Man and Mystery in Asia (London: Edward Arnold, 1924), part 3; Stephan, Sakhalin, p. 187. 


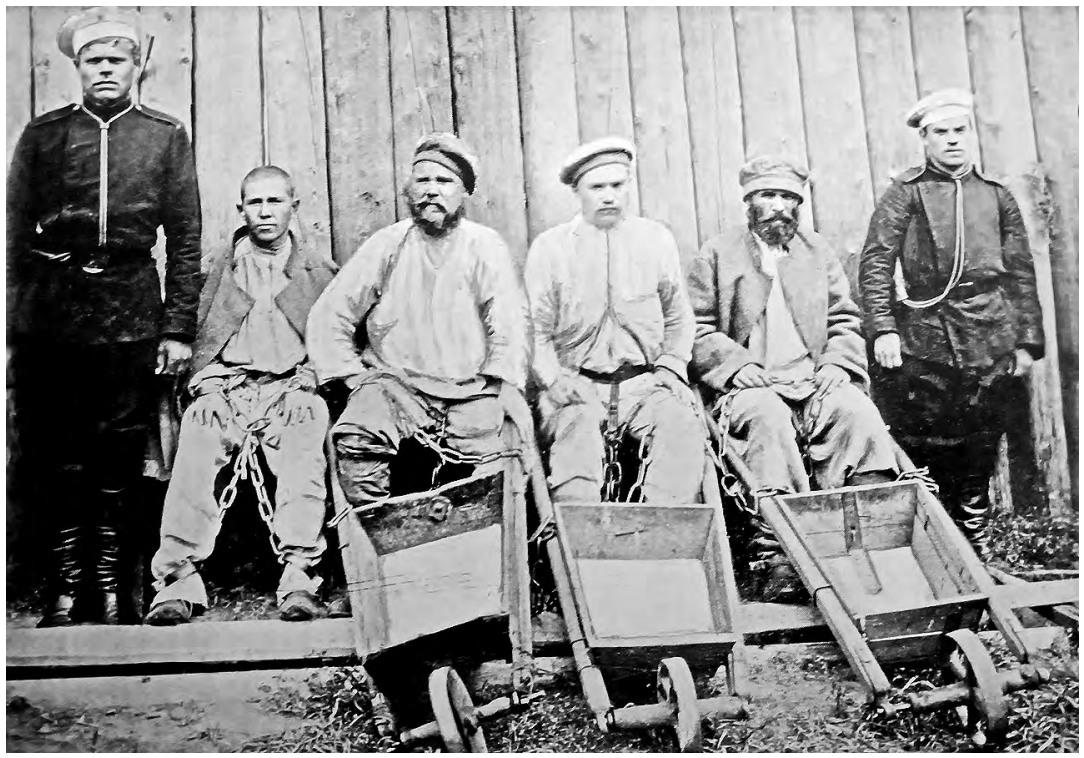

Figure 6.2. Prisoners in the Sakhalin penal colony.

Source: Charles H Hawes, In the Uttermost East (London and New York: Harper and Brothers, 1903).

Yet at another level, the redefined region provided a stage for a newly defined group of people, the 'Amurians' (Amurtsy), later 'Trans-Amurians' (Zaamurtsy), who promoted the study, exploration and colonisation of the Amur region, and, from the mid-1890s onwards, sought to use the area as a base for Russian expansion into Manchuria. Nationalist, scientifically minded and often possessing close links with scholars in China and Japan, they included such figures as the army-officer-turned-ethnographer Vladimir Klavdievich Arsen'ev (1872-1930), whose semifictional memoir Dersu Uzala (published in 1921) was to have an enormous impact on popular imaginings of the region. Arsen'ev's work can be seen as a classic example of 'imperial nostalgia'. ${ }^{22}$ Told from the perspective of an army officer (Arsen'ev himself) sent to survey the coastal region south of the mouth of the Amur in the first decade of the twentieth century, it depicts the area as a wilderness of great and untapped natural wealth, an exotic realm where Nanai and other indigenous people coexist with Chinese brigands, Korean settlers and communities of Russian religious dissenters. Within this realm Arsen'ev plays the role of the bearer of modern

22 Renato Rosaldo, Culture and Truth: The Remaking of Social Analysis (Boston: Beacon Press, 1993), pp. 68-87. 
civilisation, an irresistible force relentlessly sweeping across the face of the earth, and leaving in its wake towns, railways, steam baths and telegraph lines. Yet Arsen'ev himself, as the harbinger of modernity, grieves for the passing of the innocent power of the wilderness: characteristics embodied in the character of the book's central figure, the Nanai tribesman Dersu Uzala, whose final fate is not only death but the obliteration of his grave by the march of progress: 'The magnificent cedars disappeared, and in their place appeared roads, embankments, excavations, mounds, grooves and pits ... Farewell Dersu!'²3

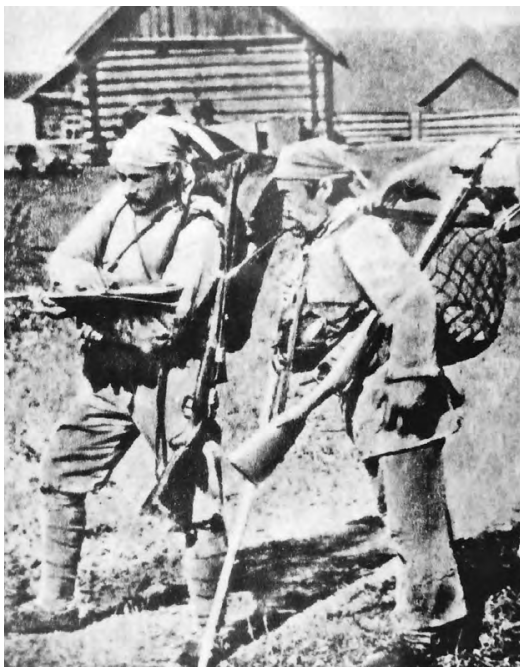

Figure 6.3. Arsen'ev with Dersu Uzala, 1906.

Source: VK Arseniev, Sobranie Sochinenil $\checkmark 6$ Tomakh, vol. 1 (Vladivostok: Rubezh, 2007).

With the coming of Stalinism, Arsen'ev was to face disgrace and persecution, and his vision of the frontier was to be overshadowed by a far more simple triumphal image of the march of progress: ' $[T]$ wenty-five settlements on the once desolate shore of the Amur estuary', proclaimed one typical report from the 1930s, 'where there stood only one or two miserable Nivkh huts, have become large villages containing hundreds of houses with electricity'. ${ }^{24}$ Yet Arsen'ev's image of the region, with its combined themes of national pride and exoticism, progress and nostalgia for lost wilderness, was to survive as an important undercurrent both in Russian and in Japanese imagery of the frontier zone, and to be given a belated revival many years later in the Japanese director Kurosawa Akira's acclaimed film version of Dersu Uzala, released in 1975.

On the Japanese side of the border, meanwhile, rapid political change was producing a new vision of the region, one which in some respects more closely paralleled earlier Russian imaginings of Siberia as a second America. In 1867, following more than 250 years of rule, the Tokugawa

23 VK Arsen'ev, Dersu Uzala: Skvol' Taigu (Moscow: Mysl', 1972), p. 228; on Arsen'ev, see also Stephan, The Russian Far East, pp. 170-72 and pp. 194-96; Slezkine, Arctic Mirrors, pp. 127-28.

24 Ni Kolesnikov, AM Boyarnik and VA Sharapov, eds, Sotsialisticheskoe Stroitel'stvo na Sakhaline 1925-1945 (Yuzhno-Sakhalinsk: Arkhivy Otdel Sakhalinskogo Obispolkoma, 1967), p. 453. 
Shogunate collapsed in the face of a military uprising by a miscellaneous group of opponents united under the banner of imperial restoration. After a relatively brief period of armed conflict, the supporters of the old regime were forced to flee north to Hokkaido, where one of their leaders, Enomoto Takeaki, sought to establish a base of opposition to the Restorationist forces by proclaiming the establishment of a 'Republic of Ezo', which drew inspiration in part from the model of the United States and in part from the ideas of Enomoto's French military adviser, Jules Brunet. Although the scheme was very short-lived, and it is uncertain how much Enomoto really knew of US political ideas, it seems likely that he (rather like Alexander Herzen) envisaged the frontier region as an unsettled space whose very emptiness made such radical political experiments possible. ${ }^{25}$

In the longer term, though, it was a new and subtly different vision of America that was to exert the greatest influence on Japanese imaginings of the north. The establishment of the Meiji government in 1868 opened the way to large-scale plans for the colonisation of Hokkaido, for which America served as a model, not simply in terms of geographical imagination, but also in much more practical ways. Of 65 Western advisers hired by the new regional administration to assist with the early development of Hokkaido, 48 were Americans, among them former US Commissioner of Agriculture Horace Capron, who in his earlier career had played a significant part in crushing Native American resistance to the colonisation of the American West. ${ }^{26}$ Capron brought with him information on the ways in which indigenous lands had been appropriated and distributed to settlers in other colonial societies including India, Australia and the US, and argued against the creation of indigenous 'reservations' on US lines, instead favouring a wholesale policy of assimilation towards the Ainu. ${ }^{27}$ This was, indeed, the policy adopted by the Meiji state, which gave the Ainu 'Japanese' names, prohibited their traditional hunting practices and instituted a vigorous program of assimilationist education for Ainu children.

25 Oyama Tsunao, 'Nichibei Bunka Sesshoku no Rekishi no naka no Hokkaido', in Hokkaidō to Amerika, ed. Sapporo Gakuin Daigaku Jinbun Gakubu (Sapporo: Sapporo Gakuin Daigaku Seikatsu Kyōdō Kumiai, 1993), p. 108.

26 Harada Kazufumi, 'Kaitakushi no Oyatoi Gaikokujin to Amerika', in Sapporo, Hokkaidō to Amerika, pp. 159 and 170; on Capron, see also Fumiko Fujita, American Pioneers and the Japanese Frontier: American Experts in Nineteenth-Century Japan (Westport, Conn.: Greenwood Press, 1994). 27 Ōsaka Shingo, Ishida Kiyotaka to Hōresu Kepron: Hokkaido Kaitaku no Nidai Onjin - Sono Shögai to sono Gyōseki (Sapporo: Hokkaidō Taumusu Sha, 1962), pp. 166-81. 
Under the influence of Capron and other American advisers, US farm tools and techniques were introduced to the region, and a system of allocating farm land to colonists (in part modelled on the principles used in the colonisation of the American west) was created. This, like equivalent schemes on the Russian side of the frontier, was of course based on the expropriation of villages and hunting grounds previously used by the indigenous people of the region. Although prison labour played an important part in the construction of roads and railways in Hokkaido, particularly in the north-eastern region surrounding the newly constructed Abashiri prison, the colonisation of the island was primarily based on the voluntary inflow of farmers and fishers from the south. In this context, 'America' was seen less as a model of political liberty than as an example of colonial development, centred upon the skill and hard work of migrant family farmers. The prominent agronomist Tsuda Sen, for example, saw Hokkaido as holding the potential for 'the creation of a United States of America within the Japanese Empire': and the America he had in mind was first and foremost the America of the Pilgrim Fathers - a place where development would be born of diligence, frugality and a pioneering spirit. ${ }^{28}$

This 'opening up' of the north was accompanied by a renaming of the region that symbolised changing official, and eventually also popular, perceptions of the frontier zone. The name 'Hokkaido' (North Sea District), based on proposals put forward by the Japanese explorer Matsuura Takeshirō, was officially bestowed on the largest and most southerly island of 'Ezo' in 1869. The name 'Ezo' itself fell into disuse, and the Okhotsk region in general came to be commonly referred to by the term 'Hoppō' (the Northern Regions). The shift was more than a semantic one. It both reflected and helped to shape changing images of the surrounding world. 'Ezo', as a word applied both to the region and its inhabitants, had been redolent with overtones of 'barbarism' in the Chinese sense of the word. 'Hoppō', on the other hand, was part of a new geography that redefined Japan in relation to the nineteenth-century global order. In this order, the two main coordinates were 'the Occident' $($ Seiyō) and 'the Orient' (Töyō). These arrived, as it were, pre-packaged by Western geography, and were accepted into Japanese thought (by and large) as immutable spatial realities. Within this dichotomy, Japan was 
inescapably assigned to the spatial realms of 'the Orient', even though various reformers might argue that, spiritually and socially, Japan should seek to escape from its Asian destiny and remake itself as part of 'the Occident'. But as far as the other two compass points - north and south - were concerned, Japanese writers had greater freedom to define their own sense of space. During the second half of the nineteenth century, the terms popularised to describe this space were, on the one hand, Nanyo or Nanpō (the South Seas or the Southern Region) and on the other Hoppō (the Northern Region). Significantly, unlike Seiyo and Töyo, these terms located Japan at the centre, with the Northern Region extending outward from Hokkaido into the Okhotsk Sea and the Southern Region stretching southward from Okinawa into Taiwan, Micronesia and ultimately the islands of Southeast Asia. They offered an imaginary panorama of Japan as a long chain of islands stretching from the frozen north to the subtropical south, and embodying a potential for expansion in either direction, or in both at once.

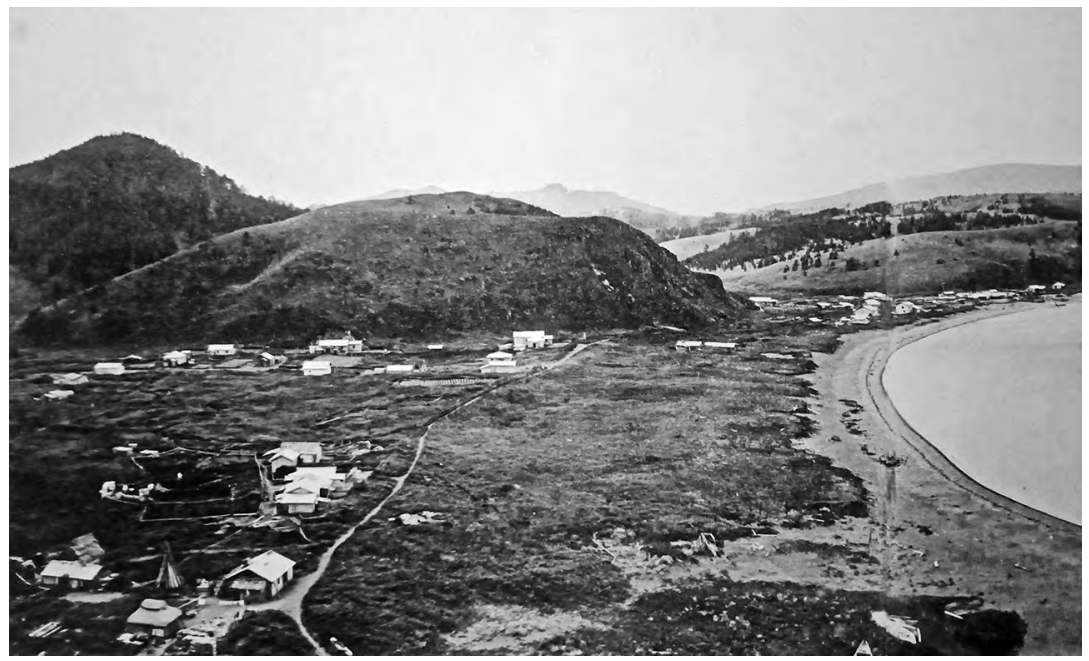

Figure 6.4. A Japanese settlement in the Habomai Islands, c. 1920.

Source: Tetsudō Shō Hokkaidō Kensetsu Jimusho, Nemuro, Nayoro, Mashike Zentsū Kinen Shashinchō (Sapporo: 1922). 
In the first half of the twentieth century it was the concept of 'southward advance' (nanshin) that would acquire the greater hold over popular imagination and practical policymaking, but during the Meiji period (1868-1912) 'northward advance' (bokushin) provided an essential testing ground for Japanese colonisation, as settlers moved first into Hokkaido and the Kurile Islands and then (after Japan's 1905 victory in the RussoJapanese War) into the regained southern half of Sakhalin (known in Japanese as Karafuto). Just as the creation of Priamur created scope for Russian 'Trans-Amurians' to dream of an expanded Asian destiny, so this northern foothold encouraged some Japanese to nurture Siberian dreams. A brief Japanese incursion into Eastern Siberia and Northern Sakhalin during the post-revolutionary chaos of the early 1920s served to heighten Soviet suspicions of such dreams, but inspired certain Japanese politicians and intellectuals to press the cause of 'northward advance' with increasing vigour. It was in this context that some Japanese officials and intellectuals encouraged dreams of an independent Yakut Republic in Siberia under Japanese tutelage (see Chapter 7), and in 1939 the Central Scientific Research Laboratory of the colony of Karafuto staged an exhibition on the development of the area it labelled 'the Northern Region of East Asia' (Tóa Hoppō). This extended the earlier and more parochial version of the 'Northern Regions' to embrace not only Karafuto but also Manchuria, Mongolia, Eastern Siberia, and the Buryat and Yakut Autonomous Regions, an area that, the organisers proclaimed, contained a total population of over 43 million people. ${ }^{29}$ In this region, just as in Southeast Asia, the exhibition's publicity argued that Japan's destiny was to reverse centuries of European colonisation and promote the vision of 'Asia for the Asians' ${ }^{30}$ All this remained, of course, no more than a dream; an illusion that was shattered by the defeat of the Japanese empire in the Asia-Pacific War.

29 Karafuto Chō Chūō Shikenjō, Karafuto Chō Chūō Shikenjō Sōritsu Jūnen Kinenshū (Toyohara: Karafuto Chō Chūō Shikenjō, 1942).

30 Anon., 'Toa Hoppo Kaihatsuten o Miru', Karafuto Jihō 29 (September 1939): p. 127. 


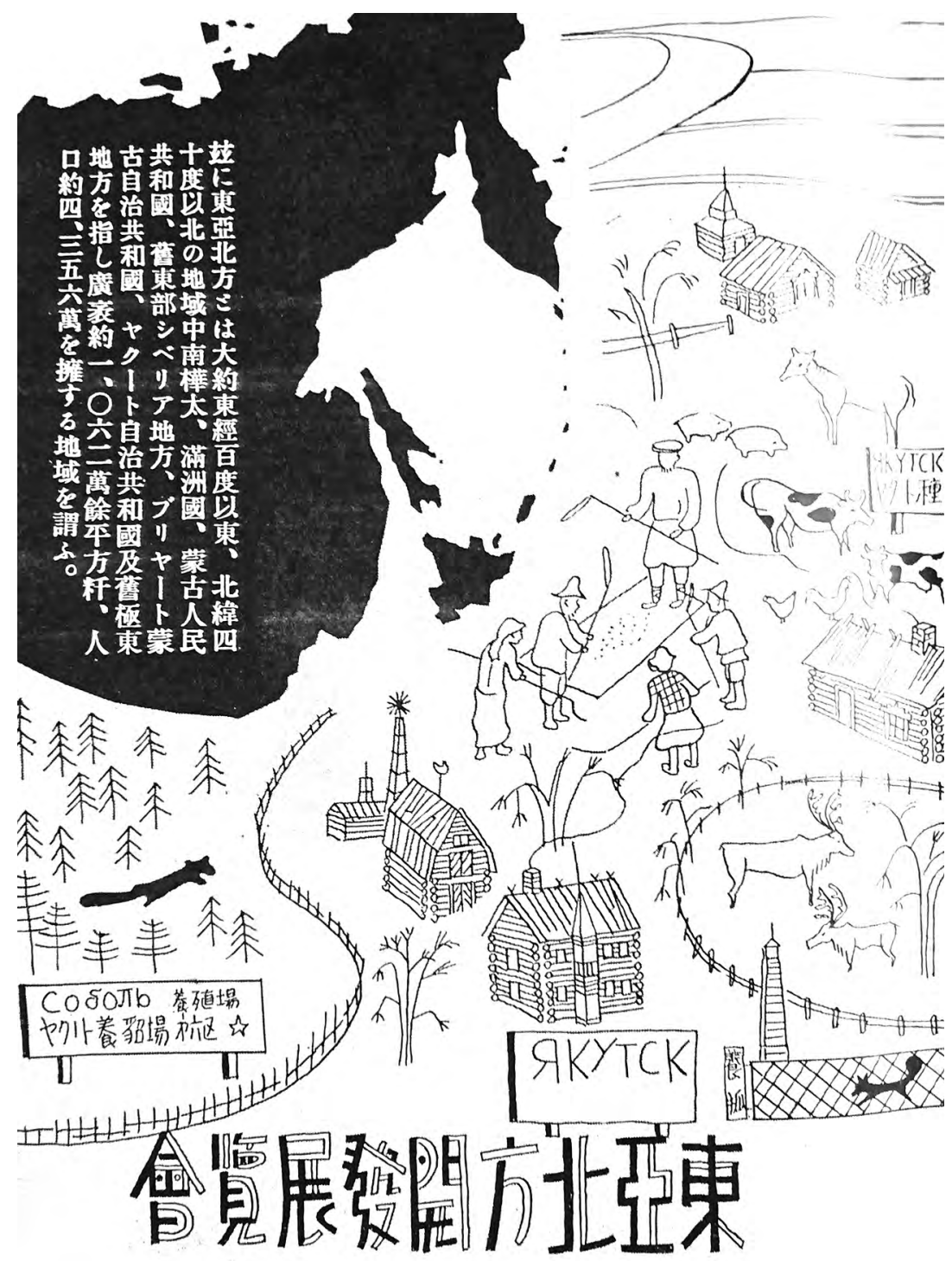

Figure 6.5. 'The Northern Region of East Asia'.

Source: Map from the 1939 exhibition by the Karafuto Central Scientific Research Laboratory. 


\section{Reimagining the Frontier}

During the very short Soviet-Japanese conflict of August to September 1945, Soviet forces swept into the southern half of Sakhalin and the Kurile island chain, creating a new national frontier that ran through the waters immediately to the north of Hokkaido. Throughout the postwar decades, Soviet ideology emphasised the image of the border zone as the vulnerable interface with the threatening forces of capitalism, and richly illustrated official publications with titles like The Frontier Gives Birth to Heroes [Granitsa Rozhdaet Geroev] glorified the courage of the soldiers and settlers who guarded the limits of the Motherland. ${ }^{31}$ On the Japanese side, meanwhile, the frontier became in many ways a forgotten region. Though heavily fortified, and the subject of repeated attempts by an assortment of political groups to stir nationalist sentiment, its impact on the public imagination was small.

After its defeat in war, the Japanese government continued to argue that sovereignty over southern Sakhalin/Karafuto had not been determined under international law. Until the end of the twentieth century, official Japanese maps of the region still showed the island as bisected by a frontier line at the 50th parallel. But no serious efforts were made by Japan to reclaim its lost colony of Karafuto, and, in a quiet act of political pragmatism, in 2001 Japan opened a consulate in Yuzhno-Sakhalinsk (previously known as Toyohara), the former capital of its colony of Karafuto, thus de facto recognising the region as part of Russia and renouncing its claim to the territory. ${ }^{32}$

The Kurile Islands, though, were another matter. In 1956, as part of the process of restoring diplomatic relations, USSR and Japan came close to resolving the issue on the basis of a so-called 'two island solution', with the southernmost islands - Shikotan and the Habomai group - being returned to Japan, while the Soviet Union would retain control of Iturup and Kunashir. But this was the height of the Cold War, and the United States, which was concerned about this potential concession to its Soviet rival, privately warned the Japanese government that if it proceeded with the agreement, the United States might refuse to return Okinawa (which had

31 Granitsa Rozhdaet Geroev (Moscow: Izdatel'stvo Dosaaf SSSR, 1976); Stephan, The Russian Far East, pp. 274-84.

32 See Kudō Nobuhiko, Waga Uchinaru Karafuto (Fukuoka: Sekifūsha, 2008), pp. 60-67. 
been under US occupation ever since Japan's wartime defeat in 1945). ${ }^{33}$ The deal fell apart, though the two island solution remained a possible compromise that was to resurface whenever relations between Japan and the Soviet Union - or its successor state Russia - seemed to be thawing. One such brief moment of thaw occurred at the end of the twentieth century, when a rapprochement between Japan and Russia produced the 'Yeltsin-Hashimoto Plan', formulated at a meeting of the two countries' leaders at Krasnoyarsk in Siberia in November 1997 and reaffirmed by their meeting at Kawana in Japan in April 1998. This set a timetable for the resolution of the border issue between the two countries, committing both governments to work towards a settlement by the end of the year 2000, but the deadline was not met, and almost two decades later the two governments were still locked in efforts to define their border in the Okhotsk.

In the postwar period, use of the expressions Nanyo or $N a n p \bar{o}$ for the regions to Japan's south fell into disuse, but the expression Hoppo was revived specifically in the context of the Hoppo Ryodo - the Northern Territories. The term 'Northern Territories' was first officially used by Japan's Foreign Ministry at the time of the 1956 negotiations, and became the official term used for the four southernmost islands from $1963 .^{34} \mathrm{By}$ the late 1960s, the phrase had become the core of a nationalist appeal for the return of this 'lost territory' spearheaded by a government-sponsored Association for Countermeasures Related to the Northern Territories (Hoppō Ryōdo Mondai Taisaku Kyōkai), ${ }^{35}$ and in 2018 the Ministry of Education announced that it would bring in guidelines to ensure that all high school students would be taught that the Northern Territories are 'an integral part of our territory'. ${ }^{36}$ As researchers like Alexander Bukh and Iwashita Akihiro have shown, though, a complex politics lies behind this reconstruction of the region's identity. The 'Northern Territories' issue has repeatedly been used by various political groups across the ideological spectrum to boost their nationalist credentials, and has at times been

33 Nobuo Shimotomai, 'The Cold War in East Asia and the Northern Territories Problem', in Northern Territories, Asia-Pacific Regional Conficts and the Aland Experience: Untying the Kurillian Knot, ed. Kimie Hara and Geoffrey Jukes (London and New York: Routledge, 2009), pp. 52-61, reference from pp. 56-57, doi.org/10.4324/9780203880166.

34 Alexander Bukh, 'Constructing Japan's "Northern Territories": Domestic Actors, Interests, and the Symbolism of the Disputed Islands', International Relations of the Asia-Pacific 12 (2012): pp. 483-509, particularly pp. 497-98, doi.org/10.1093/irap/lcs008.

35 Bukh 'Constructing Japan's "Northern Territories", pp. 497-98.

36 "Kōkyō Jugyō": Shinbun ya Tōkei Katsuyō - Kōkō Shidō Yōryo no Kaisetsusho Happyō’, Yomiuri Shimbun (Tokyo Edition), 18 July 2018, p. 29. 
strongly promoted by the Hokkaido Prefectural government to strengthen its hand in power struggles with the central government. ${ }^{37}$ But the people most directly affected by the issue - the former residents of the islands and their descendants, many of whom now live in the town of Nemuro, nearest to the disputed territories - tend to have a distinctively different perspective on the matter. For many of them, the crucial issue is less the return of Japanese territory than the opportunity to visit family graves on the islands, and to have access to the vital fishing grounds that surround the area. Opinion surveys have shown that majority local opinion supports a compromise solution, rather than insistence on the return of all the disputed islands, if it can help to ensure that access. ${ }^{38}$

On the Russian side of the divide, as Paul Richardson has vividly shown, the Kurile Islands have become a similarly symbolic touchstone in domestic politics, deployed by diverse groups of political and intellectual elites in support of their own particular constructions of national identity. Richardson broadly defines three visions of the islands that have emerged in the post-Soviet Era. From the 1990s, a group of 'liberal institutionalists' argued for a compromise settlement with Japan as a means of demonstrating post-Soviet Russia's credentials as a 'good citizen' on the international stage. They were countered by a group of 'territorial imperativists' who evoked the history of the nation's past glories and sacrifices to support their insistence that the southern Kuriles should never be surrendered to Japan. Third, a group whom Richardson call's 'pragmatic patriots' (and who include President Vladimir Putin) argue for strategic negotiations and compromises with Japan, and are potentially willing to sacrifice some territory in search of their overriding goal of securing Russia's future as a global great power. ${ }^{39}$

Putin's strategic nationalism has been paralleled by that of Japanese Prime Minister Abe Shinzō. Abe takes a particularly hardline stance on Japan's two other territorial disputes - with China over control of the Senkaku or Diaoyu Islands and with Korea over the little islet of Dokdo or Takeshima - but in the Kurile Islands dispute, he evidently sees an opportunity for a diplomatic breakthrough in a region riven by international tensions. In November 2018, the governments of Japan and Russia announced

37 Bukh 'Constructing Japan's "Northern Territories"; Akihiro Iwashita, Japan's Border Issues: Pitfalls and Prospects (London and New York: Routledge, 2015).

38 Iwashita, Japan's Border Issues, p. 51.

39 Paul B Richardson, At the Edge of the Nation: The Southern Kurils and the Search for Russia's National Identity (Honolulu: University of Hawai i Press, 2018). 
a renewed determination to reach an overall settlement on the basis of the compromise two island solution proposed in 1956, though this again has yet to produce results. ${ }^{40}$ These moves were accompanied by the revival of even more concrete visions of a bridging of the divide between the two nations. During the first decade of the twenty-first century, Russian officials touted the idea of a cross-border tunnel linking Hokkaido and Sakhalin, and in June 2018 President Putin instructed his cabinet to develop a plan to build two bridges - one between Hokkaido and Sakhalin and the other between Sakhalin and mainland Siberia, thus linking Japan directly to the Asian continent. ${ }^{41}$ What will come of this ambitious scheme remains to be seen. More surprisingly, perhaps, in December 2018 Putin also announced his government's intention officially to recognise the Ainu as one of the indigenous peoples of Russia ${ }^{42}$ - a move that could be read either as a belated acknowledgement of a historical fact (that Ainu were in fact indigenous inhabitants of the Kuriles, the southern tip of Kamchatka and southern Sakhalin, and some of their descendants still live in Russia), or as a strategic move to undermine those Japanese claims to the territory that have been based on the status of 'our' Ainu as the original inhabitants of the Kurile Islands.

Meanwhile, other less official dreams for the region also began, more quietly, to make themselves heard. The Pacific War and the Cold War that followed completed the gradual process by which centuries of contact between indigenous groups in the Okhotsk region was severed. Most of the Ainu inhabitants of Sakhalin were 'repatriated' after the war to Hokkaido - a place many of them had never seen before - and they were later followed by a small number of other indigenous people who had lived in the Japanese half of the island before the war (see Chapter 7). For decades, the border left these people almost wholly isolated from friends and relatives on the Russian side of the frontier. But by the end of the twentieth century that was changing. Visiting Japan for the first time in September 1997, the Sakhalin Nivkh activist and poet Vladimir Sangi participated in a forum attended by a number of Hokkaido Ainu and descendants of Ainu and Uilta evacuated from Sakhalin to Japan after

40 Dmitri V Streltsov, 'Will Japan and Russia Really Settle their Territorial Dispute?' The Diplomat, 15 November 2018, thediplomat.com/2018/11/will-japan-and-russia-finally-settle-their-territorialdispute/ (accessed 20 December 2018).

41 'Putin Poruchil Pravitel'stvu Prorabotat' Vopros Postroiki Mosta na Sakhalina', RBC, 24 June 2018, www.rbc.ru/society/24/07/2018/5b570abe9a79478fca3837da (accessed 2 January 2019).

42 'Ainu Minzoku wa "Roshia Senjū Minzoku”: Pūchin Shi ga Nintei Hōshin', Hokkaidō Shimbun, 19 December 2018, p. 2. 
the Pacific War. ${ }^{43}$ There he and others spoke of the destruction wrought both on the environment and on the lives of the indigenous population by earlier policies of 'opening up' the frontier region and emphasised the need for the indigenous people of the region to have an active voice in any decisions about the future of the disputed islands. ${ }^{44}$ Some Ainu activists, too, point out (with good reason) that it is the Ainu people who historically have the oldest claim to the disputed northern islands. ${ }^{45}$

These voices suggest other perspectives for looking at the past and present of the region. The frontier is a place where national governments negotiate or contest the geographical limits of their power, and where citizens of the nations on either side create their dreams of other worlds. But national borders are also lines that carve their way straight through the lives of those who inhabit the territories they bisect. In the following chapter we shall take one point on the border that bisected Sakhalin Island as a vantage point for exploring this experience of division and its implications for the indigenous people of the region.

This chapter is a revised version of an article that first appeared in the journal Pacific Affairs 72, no. 1 (1999): pp. 57-77.

43 Vladimir Sangi, address to seminar 'Saharin Shosu Minzoku no Kako to Genzai' ['The Ethnic Minorities of Sakhalin: Past and Present'], Hokkaido Museum of Northern Peoples, Abashiri, 20-21 September 1997.

44 Sangi, address to seminar 'Saharin Shōsū Minzoku no Kako to Genzai'.

45 See, for example, Alexander Bukh, 'Ainu Identity and Japan's Identity: The Struggle for Subjectivity', The Copenhagen Journal of Asian Studies 28, no. 2 (2010): pp. 35-53, reference from pp. 46-49, doi.org/10.22439/cjas.v28i2.3428. 
This text is taken from On the Frontiers of History: Rethinking East Asian Borders, by Tessa Morris-Suzuki, published 2020 by ANU Press, The Australian National University, Canberra, Australia.

doi.org/10.22459/OFH.2020.06 